\title{
Human Computer Interaction Pengelolaan Open Journal Systems berbasis Interaction Framework
}

\author{
Endang Retnoningsih ${ }^{1, *}$, Ari Nurul Alfian ${ }^{2}$ \\ ${ }^{1}$ Sistem Informasi; Universitas Bina Insani; Jl. Siliwangi No.6 Rawa Panjang Bekasi Bekasi \\ Timur 17114 Indonesia, Telp. (021) 82436886 / (021) 82436 996. Fax. (021) 824009 24; e- \\ mail: endang.retnoningsih@binainsani.ac.id \\ ${ }^{2}$ Manajemen Informatika; Universitas Bina Insani; Jl. Siliwangi No.6 Rawa Panjang Bekasi \\ Bekasi Timur 17114 Indonesia, Telp. (021) 82436886 / (021) 82436 996. Fax. (021) 824009 \\ 24; e-mail: arin@binainsani.ac.id
}

Korespondensi: email: endang.retnoningsih@binainsani.ac.id

Diterima: 8 Mei 2020; Review: 16 Mei 2020; Disetujui: 22 Mei 2020

Cara sitasi: Retnoningsih E. 2020. Human Computer Interaction Pengelolaan Open Journal Systems berbasis Interaction Framework. Bina Insani ICT Journal. 7 (1): 95-104

\begin{abstract}
Abstrak: Open Journal Systems (OJS) adalah aplikasi perangkat lunak open source untuk mengelola dan menerbitkan jurnal ilmiah, untuk mendukung fungsinya tersebut Open Journal Systems (OJS) secara umum memiliki fitur yang dalam perkembangan setiap versinya mengalami perbaikan dan penyesuaian dengan kebutuhan. Proses penerbitan jurnal sangat berdampak pada proses akreditasi jurnal, oleh karena itu perlu dipahami proses bisnis alur pengiriman artikel dari author menggunakan Open Journal Systems (OJS) hingga artikel di publish. Dalam sistem diperlukan pemodelan perencanaan, desain dan penggunaan interface antara pengguna dan komputer, interaksi ini dikenal sebagai interaksi antara manusia dengan komputer (Human Computer Interaction). Framework digunakan untuk memahami interaksi sistem komputer memberikan fasilitas bahasa antara bahasa user dan bahasa sistem. Pengguna (user) dan sistem komputer (system) dapat saling berinteraksi menggunakan beberapa cara interaksi yaitu style kombinasi form fill-in dan direct manipulation. Open Journal Systems (OJS) 3.x. memiliki tampilan yang lebih ringkas, mudah dan flexible karena dibangun dengan prinsip Interaction Framework melibatkan user, input, system, output.
\end{abstract}

Kata kunci: framework, $\mathrm{HCl}$, jurnal, OJS, PKP

Abstract: Open Journal Systems (OJS) is an open source software application to manage and publish scientific journals, to support this function Open Journal Systems (OJS) generally has features that in each version's development experience improvements and adjustments to the needs. The process of publishing a journal greatly affects the accreditation process of the journal, therefore it is necessary to understand the business process of sending articles from the author using Open Journal Systems (OJS) until the article is published. In the system required modeling planning, design and use of interfaces between users and computers, this interaction is known as the interaction between humans and computers (Human Computer Interaction). Framework is used to understand the interaction of computer systems to provide language facilities between the user's language and system language. Users (users) and computer systems (systems) can interact with each other using several modes of interaction, namely the combination style form fill-in and direct manipulation. Open Journal Systems (OJS) 3.x. has a more concise, easy and flexible appearance because it is built on the principle of Interaction Framework involving users, input, system, output.

Keywords: framework, $\mathrm{HCl}$, journals, OJS, PKP 


\section{Pendahuluan}

Open Journal Systems (OJS) adalah aplikasi perangkat lunak sumber terbuka untuk mengelola dan menerbitkan jurnal ilmiah [1]. Awalnya dikembangkan dan dirilis oleh Public Knowledge Project (PKP) pada tahun 2001 untuk meningkatkan akses ke penelitian, ini adalah platform penerbitan jurnal sumber terbuka yang paling banyak digunakan, dengan lebih dari 10.000 jurnal menggunakannya di seluruh dunia. Open Journal Systems (OJS) bersumber terbuka yang dirilis di bawah lisensi GPL v2 sumber terbuka. Open Journal Systems (OJS) bebas diunduh, digunakan, dan dimodifikasi tanpa biaya didistribusikan memakai open source GNU General Public License dan di dokumentasinya menggunakan lisensi dari Creative Commons-BY. Open Journal Systems (OJS) tersedia secara bebas untuk jurnal di seluruh dunia untuk tujuan menjadikan penerbitan akses terbuka menjadi opsi yang layak untuk belajar, meneliti dan mengubahnya. Open Journal Systems (OJS) dapat menyesuaikan dengan https://www.google.com dan https://scholar.google.com, sehingga artikel yang dipublikasikan menggunakan jurnal online melalui Open Journal Systems (OJS) dapat terindeks oleh Google dan Google Scholar [2]. Berdasarkan sejarah Open Journal Systems (OJS) telah berkembang beberapa versi [1]. Perkembangan Open Journal Systems (OJS) sebagaimana pada tabel 1.

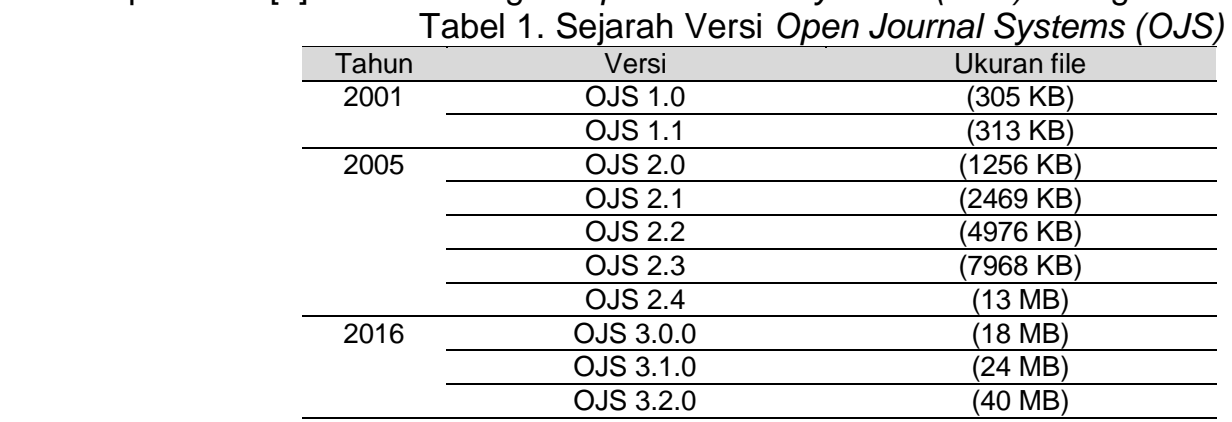

Sumber: https://pkp.sfu.ca/ojs (2020)

Berdasarkan sejarahnya yang cukup lama, tidak diragukan lagi kemampuan Open Journal Systems (OJS) sebagai perangkat lunak (sistem) yang memiliki kemampuan pengelolaan jurnal secara online. Open Journal Systems (OJS) memiliki tampilan menarik, dan performa stabil untuk mendukung publikasi artikel ilmiah, untuk mendukung fungsinya tersebut Open Journal Systems (OJS) secara umum memiliki fitur yang dalam perkembangan setiap versinya mengalami perbaikan dan penyesuaian dengan kebutuhan [3]:

Tabel 2. Fitur Open Journal System (OJS)

\begin{tabular}{cl}
\hline No & \multicolumn{1}{c}{ Fitur Open Journal Systems (OJS) } \\
\hline 1 & Dikembangkan oleh berbagai developer \\
\hline 2 & Memiliki standar sistem kelas dunia \\
\hline 3 & Memiliki plug-in dan framework \\
\hline 4 & Efektif untuk penenbitan \\
\hline 5 & Dapat diinstall pada server local \\
\hline 6 & Proses bisnis OJD dapat dikonfigurasi oleh Editor \\
\hline 7 & Dapat dilakukan online submission, Review secara double blind, kendali menajemen konten \\
\hline 8 & Adanya pembatasan hal pembaca memalui modul subcription \\
\hline 10 & Fitur Modul Pembayaran \\
\hline 11 & Editor dapat menampilkan informasi yang relevan yang relevan \\
\hline 12 & Notifikasi komen reader terhubung langsung ke email \\
\hline 13 & Dilengkapi fitur pengarsipan \\
\hline
\end{tabular}

Sumber: Handoko, et al. (2017)

Manajemen Open Journal Systems (OJS) secara umum terbagi menjadi 3 (tiga) bagian besar yaitu Bagian Manajemen, Bagian Pengguna, dan Bagian Peran. Untuk dapat menjalankan Open Journal Systems (OJS), sebelumnya perlu dilakukan instalasi Open Journal Systems (OJS), kebutuhan sistem guna mendukung instalasi Open Journal Systems (OJS) diperlukan system requirements [4] yaitu: 1) PHP 5.3.7 atau with MySQL or Postgre support; 2) Sebuah Database server : MySQL 4.1, PostgreSQL 9.1.5 or Laragon; 3) Rekomendasi UNIXlike OS (Linux, FreeBSD, Solaris, Mac OS X, dsb).

Dalam pembangunan sistem diperlukan sebuah pemodelan yang merupakan perencanaan, desain dan penggunaan interface antara pengguna dan komputer melalui 
website maupun mobile untuk berinteraksi dengan sistem. Interaksi ini dikenal sebagai interaksi antara manusia dengan komputer (Human Computer Interaction). Banyak bidang $\mathrm{HCl}$ berkembang dengan teknis baru dalam ilmu komputer, mengeksplorasi sifat-sifat dari sistem interaktif, tren jangka panjang yang dihasilkannya adalah menciptakan bidang-bidang yang secara metodologis mengembangkan 'teori $\mathrm{HCl}$ ' universal. Pemrograman biasanya difokuskan pada para programmer, dan berusaha membangun model berdasarkan prosesnya, merupakan cara dari $\mathrm{HCl}[5]$.

Pemodelan Human Computer Interaction $(\mathrm{HCl})$ merupakan tindakan alamiah dan bagaimana tindakan tersebut dapat terstruktur. Peran utama interaksi untuk menghasilkan sistem yang mudah digunakan, efisien, aman dan efektif bagi pengguna. Dalam $\mathrm{HCl}$ adanya interaksi antara manusia dengan sistem melibatkan komponen yaitu pengguna, interaksi dan sistem [6]. Kunci utama $\mathrm{HCl}$ adalah daya guna (usability), yang berarti sistem harus mudah digunakan, memberikan keamanan kepada pengguna, mudah dipelajari. Prinsip usability mengarahkan para desainer interface untuk menghasilkan antarmuka sistem yang dapat digunakan harus sederhana dan fokus pada bagian sistem yang dibangun [7]. Awalnya $\mathrm{HCl}$ berfokus pada bagaimana pengguna merasa nyaman untuk menggunakan komputer [8].

Framework digunakan untuk memahami interaksi sistem komputer. Mengasumsikan bahwa pengguna dan sistem memiliki bahasa unik masing-masing dan interaksi yang terjadi memberikan fasilitas bahasa antara bahasa user dan bahasa sistem. Maka diperlukan sebuah framework yang menyediakan konteks menggambarkan struktur untuk mengidentifikasi area permasalahan dalam desain. Interaction framework memiliki empat bagian seperti pada gambar 1 terdiri dari user, input, system, output [9].

Sumber: Dix, et.al (2013)

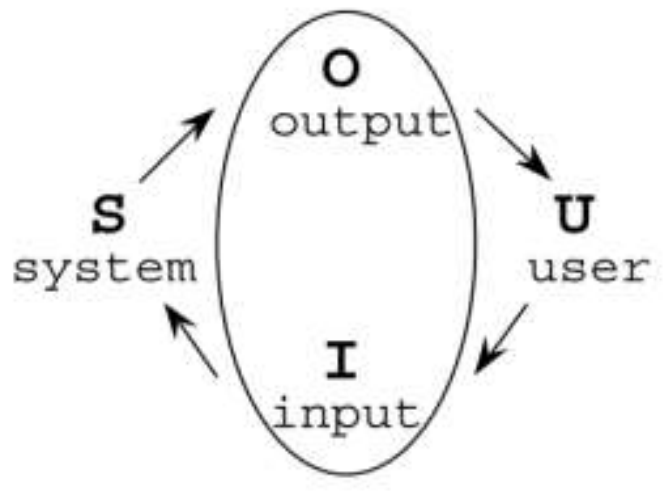

Gambar 1. Interaction Framework

Pengguna (user) dan sistem komputer (system) dapat saling berinteraksi menggunakan beberapa cara interaksi (interaction style) seperti comand line, menu selection, form fill-in, direct manipulation dan anthropomorphic dalam sistem web maupun desain aplikasi [10]. Pada penelitian ini merupakan style kombinasi form fill-in dan direct manipulation. Kelebihan dan kekurangan dari interaction style seperti disajikan pada tabel 3.

\begin{tabular}{|c|c|c|}
\hline Interaction style & Kelebihan & Kekurangan \\
\hline \multirow[t]{3}{*}{ Form Fill-in } & Format sudah dikenali. & Memakan ruang layar. \\
\hline & Menyederhanakan input informasi. & $\begin{array}{l}\text { Membutuhkan desain yang efisien dan } \\
\text { teliti. }\end{array}$ \\
\hline & Tidak memerlukan banyak pelatihan. & $\begin{array}{l}\text { Tidak mengantisipasi kesalahan } \\
\text { penulisan. }\end{array}$ \\
\hline \multirow[t]{6}{*}{ Direct Manipulation } & Pembelajaran lebih cepat. & Kompleksitas desain yang lebih tinggi. \\
\hline & Mudah diingat. & Membutuhkan pengenalan icon/simbol. \\
\hline & Mengekploitasi isyarat visual. & $\begin{array}{l}\text { Kurang efisien bagi pengguna yang } \\
\text { terbiasa mengetik. }\end{array}$ \\
\hline & Mudah dalam penanganan kesalahan. & $\begin{array}{ll}\text { Meningkatkan } & \text { kemungkinan } \\
\text { kekacauan pada layar. } & \\
\end{array}$ \\
\hline & $\begin{array}{l}\text { Menampilkan objek yang lengkap, tepat } \\
\text { dan berkesinambungan. }\end{array}$ & \\
\hline & $\begin{array}{l}\text { Memperoleh feedback secara langsung } \\
\text { dari aksi yang dilakukan. }\end{array}$ & \\
\hline
\end{tabular}


Kegagalan membangun sistem (disebabkan karena pengguna tidak dapat berinteraksi dengan antarmuka dari sistem tersebut. Untuk menghasilkan sistem yang interaktif dapat memperhatikan secara keseluruhan bagian dalam pengembangan sistem user interface dalam ISO 13407 menjelaskan proses desain yang berpusat pada manusia atau pengguna [11].

\section{Metode Penelitian}

Dalam ISO 13407 prinsip desain yang berpusat pada pengguna harus memperhatikan keterlibatan pengguna secara aktif. Adapun aktifitas dasar dalam desain interaksi yaitu [10]:

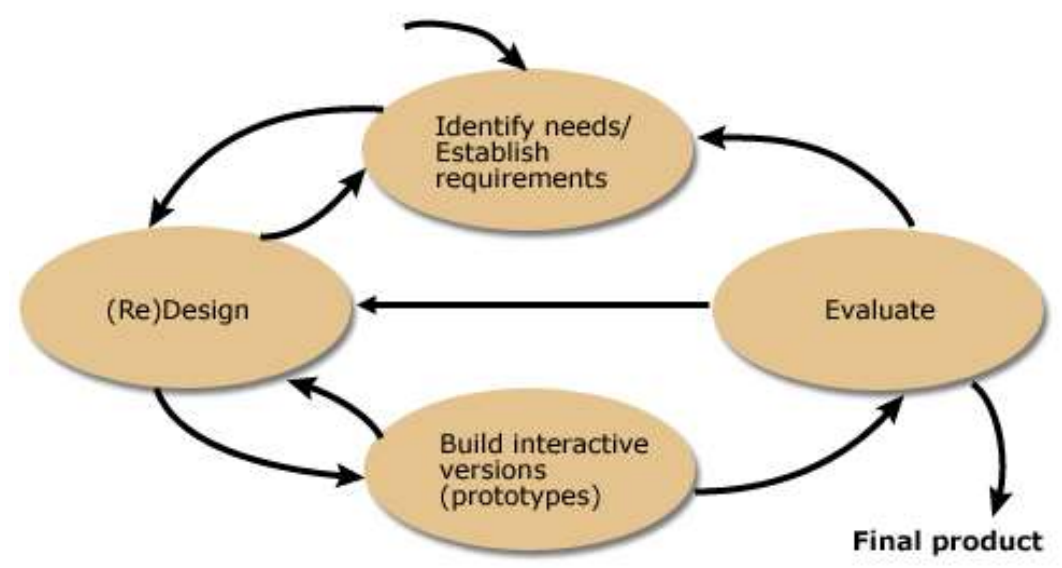

Sumber: Sabariah, dkk (2017)

\section{Gambar 2. Model Desain Interaksi}

Identify needs/Establish requirements, mengidentifikasi apa yang diinginkan dan membangun kebutuhan. Diawali dengan mengetahui target pengguna, kemudian mendefinisikan personal pengguna, dari personal tersebut dapat diketahui apa yang pengguna inginkan dan didefinisikan kedalam kebutuhannya. Kategori pengguna seperti pengguna primer yang langsung menggunakan dan frekuensinya sering, pengguna sekunder yang frekuensi penggunaannya sesekali dan melalui orang lain, pengguna tertiary yang penggunaannya dipengaruhi karena diperkenalkan pihak lain. Mengidentifikasi kebutuhan digunakan untuk mencapai kesamaan antara persepsi kebutuhan dari sisi pengembang sistem dan dari sisi personal pengguna [12]

Re (Design), mengembangkan alternatif desain melalui analisa atau heuristic evaluation, yaitu melakukan evaluasi dengan menggunakan pengukuran usability. Heuristic evaluation untuk menemukan problem kegunaan dalam mendesain sebuah interface merupakan bidang $\mathrm{HCl}$ [13]. Visibility of system status, salah satu instrumen dalam pengujian heuristic evaluation untuk mengetahui bahwa sistem selalu menginformasikan kepada pengguna berkaitan proses yang sedang berlangsung [14].

Build Interactive, membangun interaktif dari desain berdasarkan goals, task dan skenario. Prototipe yang dihasilkan kemudian dievaluasi sampai mendapatkan desain yang sesuai dengan kebutuhan pengguna.

Evaluate, mengevaluasi desain yaitu melakukan pengujian dari desain yang sudah dirancang. Dalam melakukan pengujian sebaiknya disusun skenario dari pengujian, kemudian diuji oleh target user yang sudah di definisikan di awal.

\section{Hasil dan Pembahasan}

Pada penelitian ini, dibahas framework interaction pada Open Journal Systems (OJS) versi 2.x (karena terdapat beberapa versi pada 2.0 sampai dengan versi 2.4.8-5) dan 3.x. (karena terdapat beberapa versi pada 3.0.0 sampai dengan versi 3.2.1-1) Sesuai dengan aktifitas dasar dalam desain interaksi berikut penjelasan dari setiap kegiatan Identify needs/Establish requirements, $R e$ (Design), Build Intercactive dan Evaluate. 


\section{Identify needs/Establish requirements}

Pembangunan sistem diperlukan sebuah pemodelan untuk dapat mengetahui apa yang pengguna inginkan diperoleh dari proses bisnis yang menggambarkan kegiatan pengguna sehubungan dengan sistem komputer. Tabel 4 menunjukkan secara lengkap interaksi yang terjadi antara pengguna sistem dengan Open Journal Systems (OJS).

\begin{tabular}{lll} 
& & Tabel 4.Interaksi pengguna sistem \\
\hline No & Open Journal Systems (OJS) & Bentuk Interaksi \\
\hline 1 & Bagian Manajemen & $\begin{array}{l}\text { Berisikan menu-menu untuk mengatur segala sesuatu yang } \\
\text { berhubungan dengan jurnal. }\end{array}$ \\
\hline 2 & Bagian Pengguna & $\begin{array}{l}\text { Berisikan menu-menu untuk mengatur pendaftaran pengguna } \\
\text { dan peran pengguna. }\end{array}$ \\
\hline 3 & Bagian Peran & $\begin{array}{l}\text { Berisikan menu-menu untuk menampilkan daftar pengguna } \\
\text { untuk masing-masing peran. }\end{array}$ \\
\hline Sumber: Hasil Penelitian OJS 2x. dan OJS 3. (2020) &
\end{tabular}

Proses penerbitan jurnal sangat berdampak pada proses akreditasi jurnal, oleh karena itu perlu dipahami proses bisnis alur pengiriman artikel dari author menggunakan Open Journal Systems (OJS) hingga artikel di publish sebagaimana pada gambar 3.

OJS Editorial and Publishing Process

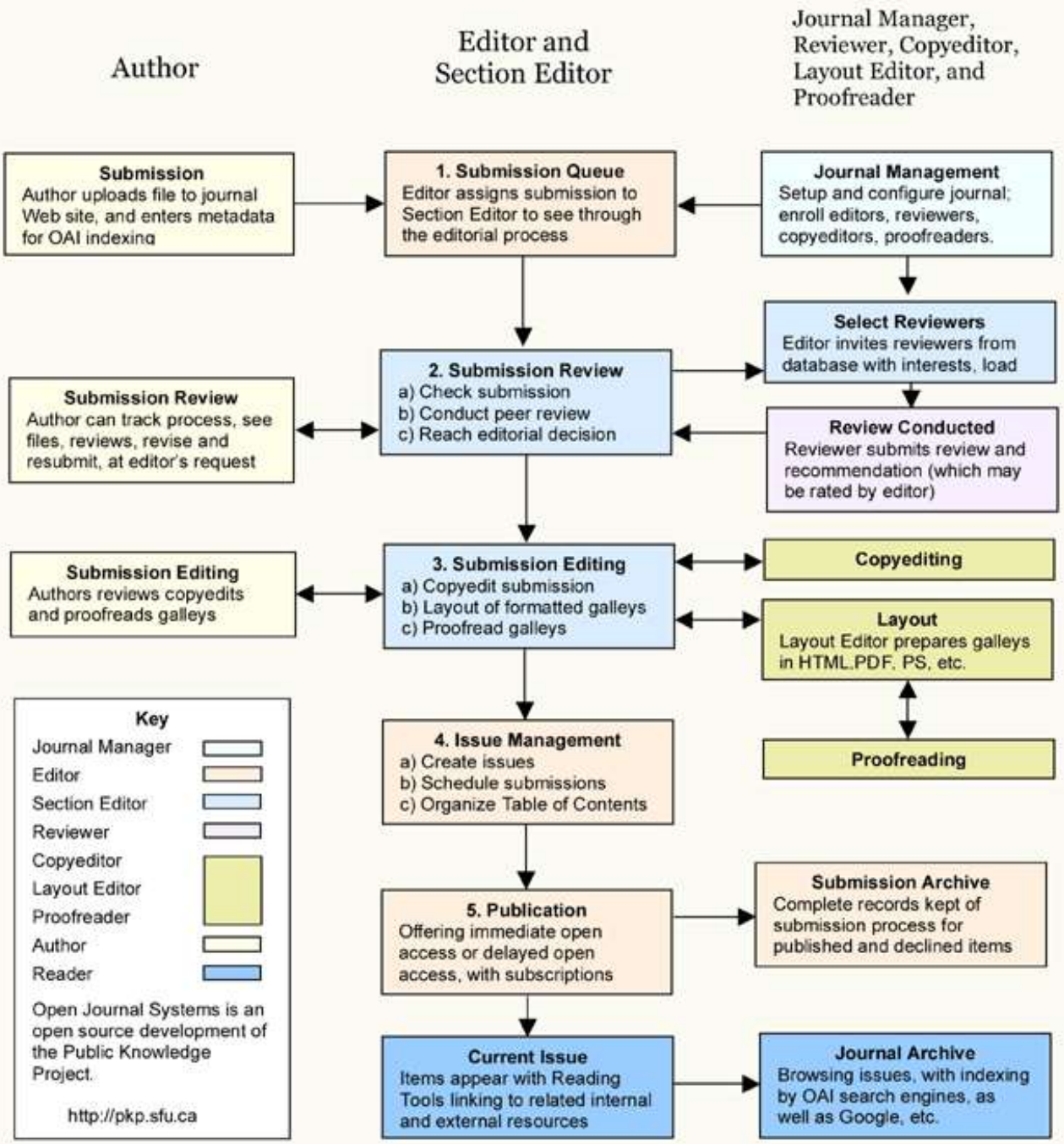

Sumber: Hasil Penelitian OJS 2.x. dan OJS 3.x. (2020)

Gambar 3. Bisnis Proses Open Journal Systems (OJS)

Artikel yang sudah dikirimkan oleh author selanjutnya diteruskan ke editor yang kemudian akan memilih siapa section editor yang bertugas dan kemudian dilanjutkan lagi ke 
reviewer. Reviewer akan memberi keputusan apakah artikel itu diterima atau ditolak, setelah itu masuk ke proses editing. Peoses editing juga melibatkan beberapa peran, yaitu copyeditor, layout, proofreader.

Bisnis proses singkat pada sebuah Open Journal Systems (OJS) adalah sebagai berikut: 1) Author register akun dan login, kemudian submit artikel kepada pengelola jurnal; 2) Author memonitor setiap tahapan dari artikel yang dikirimkan; 3) Editor memeriksa artikel yang masuk, kemudian mengundang dua atau lebih reviewer ; 4) Editor menerima hasil artikel yang telah direview, kemudian mengirimkan kepada Author untuk di re-submit; 5) Editor melakukan copyedit, membuat layout galleys, dan profread; 6) Editor membuat issue yaitu menentukan volume jurnal, edisi dan tahun publish, dan melakukan daftar konten artikel yang akan di publish; 7) Editor dapat melihat editorial history dari setiap artikel yang masuk hingga proses publish; 8) Jika sudah sesuai selanjutnya editor proses publish sesuai dengan issue dan tanggal terbit; 10) Setelah jurnal publish, maka secara otomatis dapat terindex oleh pengindex seperti OAl search engines, Google Scholar, Scopus, dan lainnya.

\section{$\operatorname{Re}($ Design)}

Mengembangkan alternatif desain dilakukan evaluasi dengan menggunakan pengukuran usability Untuk dapat mengukur usability sistem dapat dilakukan dengan pengujian heuristic evaluation, seperti pada gambar 4 merupakan instrumen dalam pengujian yaitu sistem selalu menginformasikan kepada pengguna berkaitan proses yang sedang berlangsung yaitu adanya progress bar yang menunjukkan capaian dari proses upload artikel file submission.

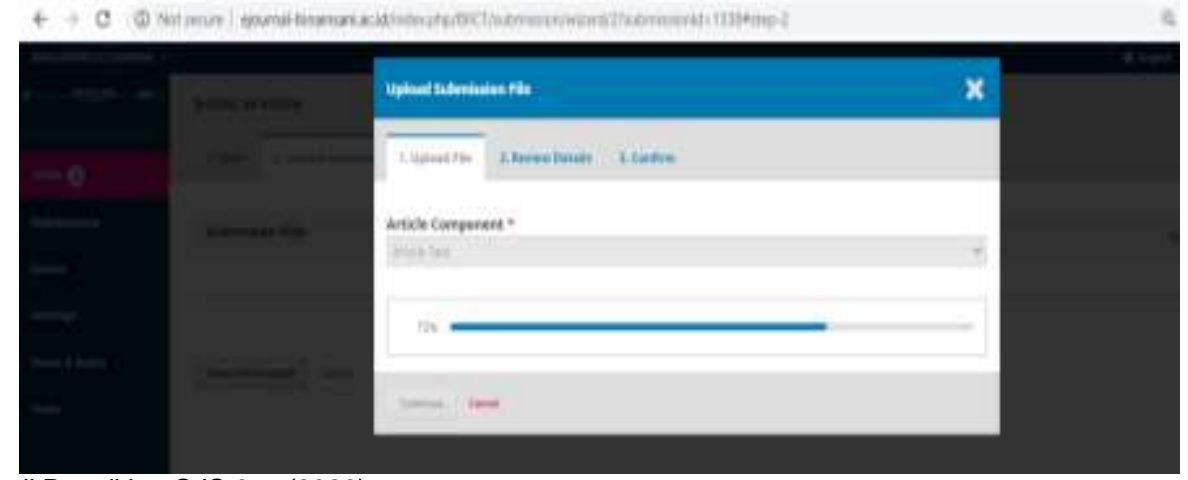

Sumber: Hasil Penelitian OJS 3.x. (2020)

Gambar 4. Heuristic Evaluation Menginformasikan Proses Sedang Berlangsung

Re (Design) Open Journal Systems (OJS) dikembangkan pula oleh para developer untuk memberikan kemudahan kepada para pengguna. Pada penelitian ini, terlihat bahwa adanya tampilan dan menu-menu yang berbeda antara Open Journal Systems (OJS) 2.x dan Open Journal Systems (OJS) 3.x tampilan yang lebih sederhana dan fokus pada bagian sistem merupakan prinsip usability dalam $\mathrm{HCl}$ berfokus pada bagaimana pengguna merasa nyaman untuk menggunakan komputer. Perubahan tampilan dan menu tampak pada tabel 5.

Tabel 5.Re-Design fungsionalitas Open Journal Systems (OJS) 2.x dan Open Journal Systems (OJS) OJS 3.x

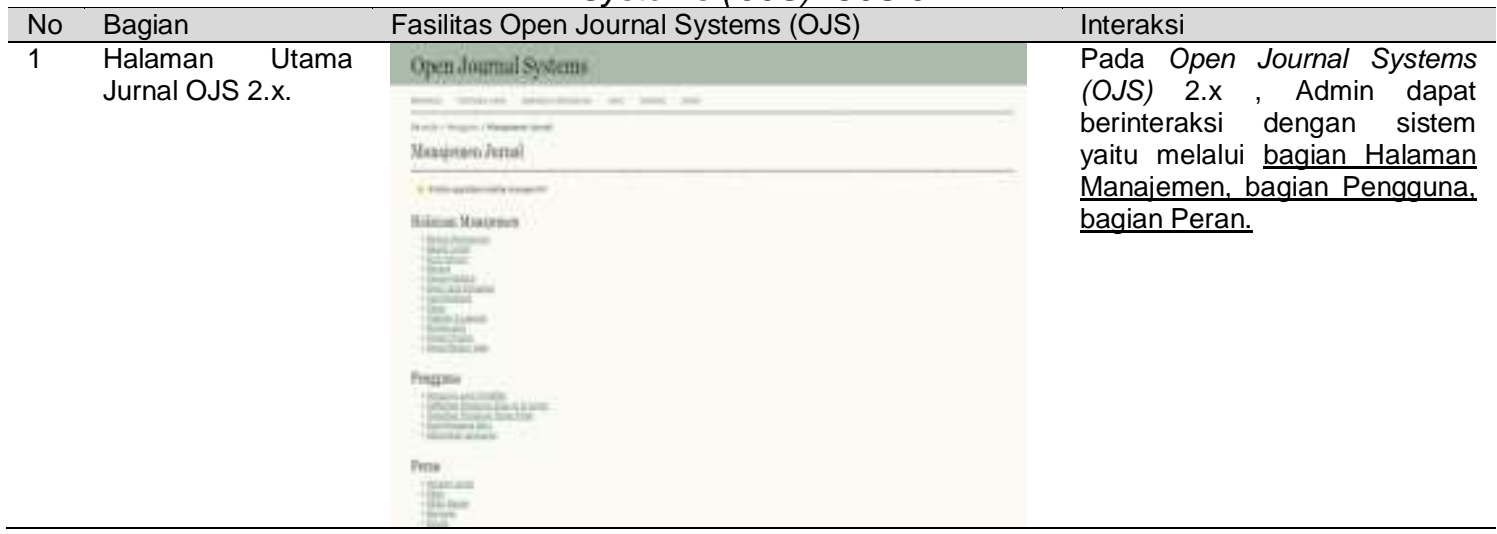


BINA INSANI ICT JOURNAL ISSN: 2355-3421 (Print) ISSN: 2527-9777 (Online); 95 - 104

\begin{tabular}{|c|c|c|c|c|}
\hline No & Bagian & Fasilitas Open & urnal Systems (OJS) & Interaksi \\
\hline 2 & $\begin{array}{l}\text { Halaman Utama } \\
\text { Jurnal OJS 3.x. }\end{array}$ & 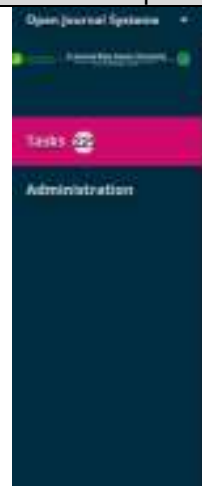 & 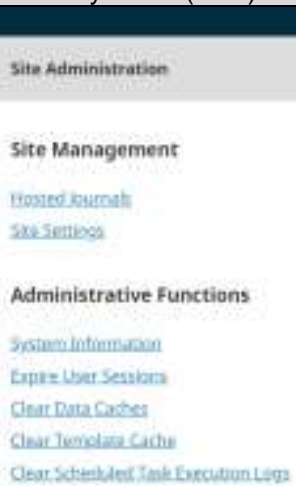 & $\begin{array}{l}\text { Pada Open Journal Systems } \\
\text { (OJS) 3.x, Admin dapat } \\
\text { berinteraksi dengan sistem } \\
\text { yaitu melalui } \\
\text { Administration. }\end{array}$ \\
\hline
\end{tabular}

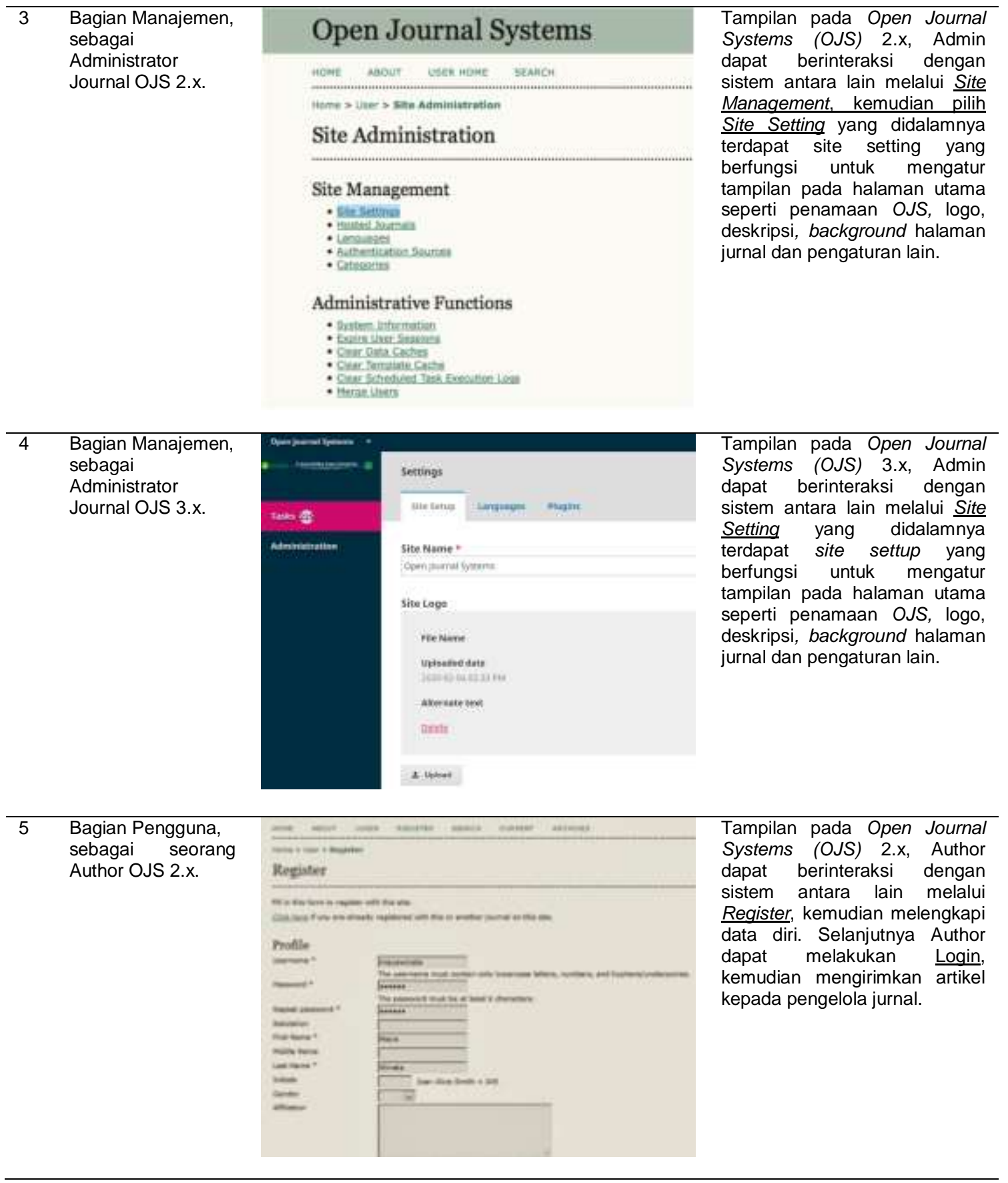




\begin{tabular}{|c|c|c|c|}
\hline No & Bagian & Fasilitas Open Journal Systems (OJS) & Interaksi \\
\hline 6 & $\begin{array}{l}\text { Bagian Pengguna, } \\
\text { sebagai seorang } \\
\text { Author OJS 3.x. }\end{array}$ & 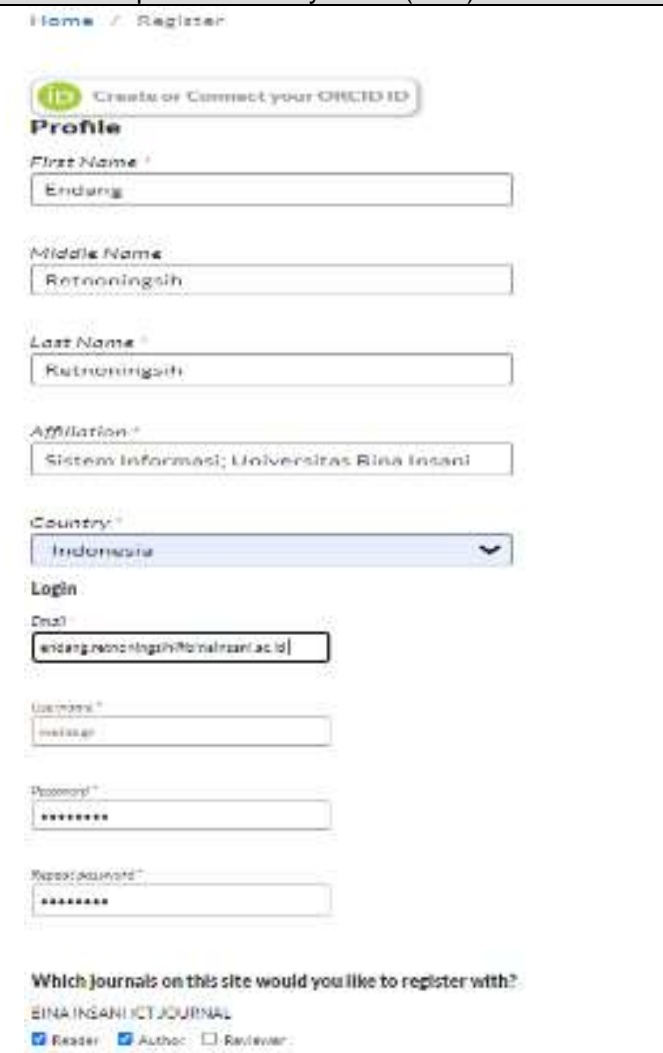 & $\begin{array}{l}\text { Tampilan pada Open Journal } \\
\text { Systems (OJS) 3.x, Author } \\
\text { dapat berinteraksi dengan } \\
\text { sistem antara lain melalui } \\
\text { Register, kemudian melengkapi } \\
\text { data diri. Selanjutnya Author } \\
\text { dapat melakukan Login, } \\
\text { kemudian mengirimkan artikel } \\
\text { kepada pengelola jurnal melalui } \\
\text { Submission. }\end{array}$ \\
\hline 7 & $\begin{array}{l}\text { Bagian Peran, } \\
\text { sebagai seorang } \\
\text { Editor OJS 2.x. }\end{array}$ & 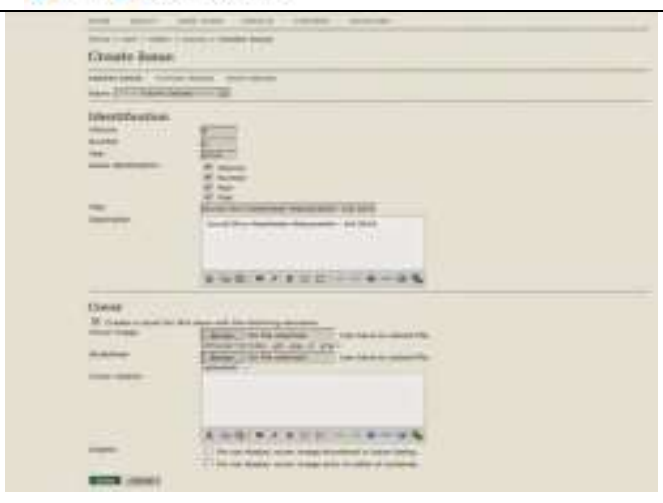 & $\begin{array}{l}\text { Tampilan pada Open Journal } \\
\text { Systems (OJS) 2.x, Editor } \\
\text { dapat berinteraksi dengan } \\
\text { sistem antara lain melalui } \\
\text { Create Issue, kemudian } \\
\text { mengisi Identification untuk } \\
\text { melengkapi data publikasi pada } \\
\text { periode yang akan di } \\
\text { publikasikan seperti: Volume, } \\
\text { Number, Year, Issue } \\
\text { Identifikation, serta Cover. }\end{array}$ \\
\hline 8 & $\begin{array}{l}\text { Bagian Peran, } \\
\text { sebagai seorang } \\
\text { Editor OJS 3.x. }\end{array}$ & 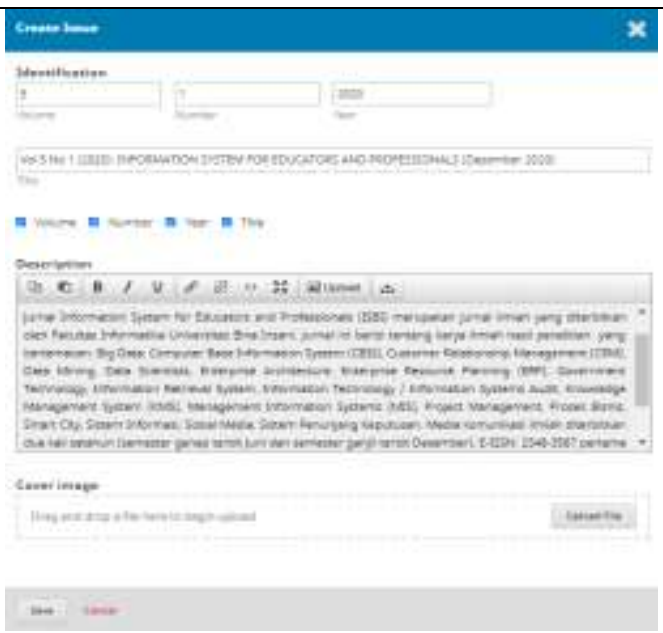 & $\begin{array}{l}\text { Tampilan pada Open Journal } \\
\text { Systems (OJS) 3.x, Editor } \\
\text { dapat berinteraksi dengan } \\
\text { sistem antara lain melalui } \\
\text { Create Issue, kemudian } \\
\text { mengisi Identification untuk } \\
\text { melengkapi data publikasi pada } \\
\text { periode yang akan di } \\
\text { publikasikan seperti: Volume, } \\
\text { Number, Year, Issue } \\
\text { Identifikation, serta Cover. }\end{array}$ \\
\hline
\end{tabular}




\section{Build Intercactive}

Membangun interaktif Open Journal Systems (OJS) pada penelitian ini adalah goals, task dan skenario melibatkan user, input, system, output. Goals pada sistem ini adalah memberikan kemudahan kepada Author sebagai user untuk dapat melakukan submit sebagai input kedalam sistem Open Journal Systems (OJS) berupa artikel kepada pengelola jurnal. Pada sistem Open Journal Systems (OJS) task dilakukan oleh author, editor dan juga reviewer. Artikel yang disubmit author diterima oleh Editor dan dilakukan review oleh Reviewer yang di tunjuk oleh pengelola jurnal, Dalam hal ini Editor juga membuat issue berkaitan dengan periode publikasi. System akan memberikan respon seterusnya terhadap interaksi yang dilakukan antara pengguna dengan system Open Journal Systems (OJS) dan skenario berakhir sampai pada artikel yang di submit telah layak dan disetujui untuk di publish.

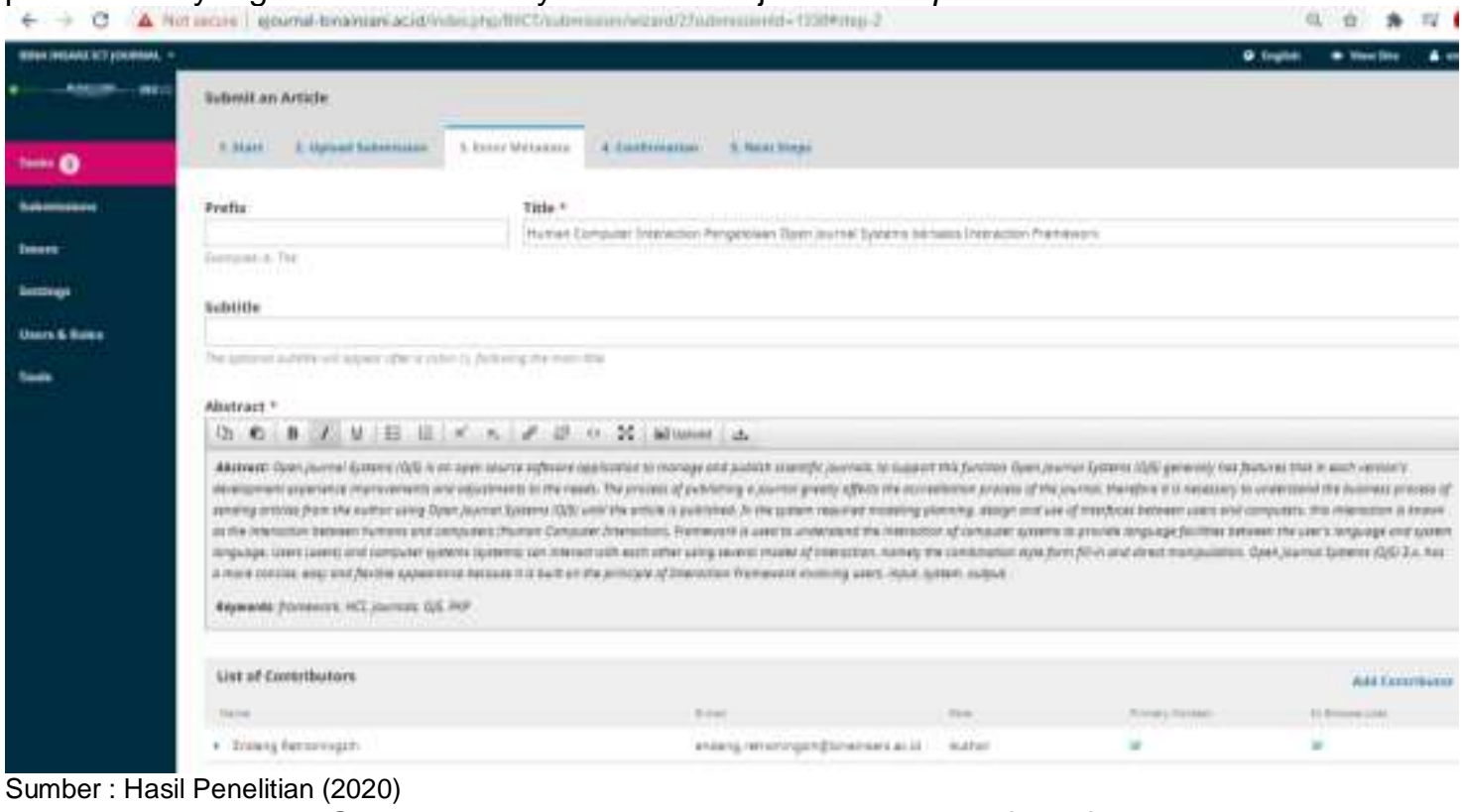

Gambar 5. Build interactive interaction style form fill-in

\section{Evaluate}

Berdasarkan tabel 3, gambar 4 merupakan bentuk interaksi style form fill-in, gambar 5 merupakan bentuk interaksi style Direct Manipulation pada Open Journal Systems (OJS) 3.x. Sehingga tampilan lebih sederhana karena format sudah dikenali, menyederhanakan input informasi dan Tidak memerlukan banyak pelatihan.

\section{Kesimpulan}

Berbeda dengan Open Journal Systems (OJS) 2.x. dengan tampilan setup yang cukup panjang, Open Journal Systems (OJS) 3.x. memiliki tampilan yang lebih sederhana, ringkas, mudah dan flexible karena dibangun dengan prinsip Interaction Framework yang melihat pada kebutuhan user, input, system, output untuk dapat saling berinteraksi menggunakan form fill-in dan direct manipulation sesuai prinsip usability dalam $\mathrm{HCl}$ berfokus pada bagaimana pengguna merasa nyaman untuk menggunakan komputer.

\section{Referensi}

[1] Public Knowledge Project (PKP), "Open Journal Systems," Website, 2020. [Online]. Available: https://pkp.sfu.ca/ojs/.

[2] I. Arief and Handoko, Jurnal Online dengan Open Journal System. Padang: Lembaga Pengembangan Teknologi Informasi dan Komunikasi (LPTIK) Universitas Andalas, 2016.

[3] Handoko, I. Arief, and Yuhefizar, No TitleKupas Tuntas Open Journal System Versi 3. Jakarta Selatan: Elex Media Komputindo, 2017.

[4] I. G. Susrama, A. Setiawan, Bi. Firensa, and R. C. Pramana, Tutorial Sederhana Menggunakan OJS-3, no. November. Sidoarjo: Pindomedia Pustaka, 2019. 
[5] A. F. Blackwell, M. Petre, and L. Church, "Fifty Years of the Psychology of Programming," Int. J. Hum. Comput. Stud., vol. 131, no. February, pp. 52-63, 2019.

[6] D. Novianti, "Sistem Informasi Keuangan Menggunakan Human Computer Interaction," INTI TALAFA J. Tek. Inform., vol. 9, no. 2, pp. 25-45, 2017.

[7] R. Firmansyah, "Evaluasi Heuristik Pada Desain Interface Aplikasi My Indihome," in Seminar Nasional Ilmu Pengetahuan dan Teknologi Komputer Nusa Mandiri (SNIPTEk), 2016, pp. 69-76.

[8] L. Punchoojit and N. Hongwarittorrn, "Usability Studies on Mobile User Interface Design Patterns : A Systematic Literature Review," J. Hindawi Adv. Human-Computer Interact., vol. 2017, 2017.

[9] A. Dix, J. Finlay, G. Abowd, and R. Beale, "Interaction Framework," in Human-Computer Interaction, United States: Prentice Hall, 1993.

[10] M. K. Sabariah, V. Effendy, and D. Junaedi, Interaksi Manusia dan Komputer. Yogyakarta: Diandra Kreatif, 2015.

[11] International Organization for Standardization, "ISO 13407: Human Centred Design Process for Interactive Systems." 1999.

[12] S. Kosasi and S. M. Kuway, "Studi Analysis Persyaratan Kebutuhan Sistem dalam Menghasilkan Perangkat," SISFOTENIKA, vol. 2, no. 1, 2012.

[13] N. L. P. A. Wedayanti, N. K. A. Wirdiani, and I. K. A. Purnawan, "Evaluasi Aspek Usability pada Aplikasi Simalu Menggunakan Metode Usability Testing," J. MERPATI, vol. 7, no. 2, pp. 113-124, 2019.

[14] U. Ependi, T. B. Kurniawan, and F. Panjaitan, "System Usability Scale Vs Heuristic Evaluation: A Review System Usability Scale Vs Heuristic Evaluation: A Review," J. SIMETRIS, vol. 10, no. 1, pp. 65-74, 2019. 